\title{
Gamma radiation effects in the brain of rats: antioxidant and radioprotective properties of Vernonia amygdalina leaf extract
}

\author{
Olatunde OWOEYE ${ }^{1,2^{*}}$, Adebukola ADESIDA ${ }^{2}$, Silas Kalu ONWUKA ${ }^{3}$ and \\ Ebenezer Olatunde FAROMBI ${ }^{2}$
}

\author{
${ }^{I}$ Department of Anatomy, College of Medicine, University of Ibadan, Ibadan, Nigeria. \\ ${ }^{2}$ Department of Biochemistry, College of Medicine, University of Ibadan, Ibadan, Nigeria. \\ ${ }^{3}$ Department of Veterinary Anatomy, Faculty of Veterinary Medicine, University of Ibadan, Nigeria. \\ *Corresponding author; E-mail: oowoeye2001@yahoo.com,o.owoeye@mail.ui.edu.ng
} Tel: +234-8033239973, Fax: 234-2-8103043

\begin{abstract}
Radiotherapy side effects have been attributed to free radical reactions. This study evaluated the antioxidant activity of the methanolic extract of $V$. amygdalina (MEVA) against gamma irradiation-induced oxidative stress in rats' brain. Seventy male rats weighing 130-160 g were randomized into seven groups, with each group comprising ten rats namely: control, MEVA at 250, and $500 \mathrm{mg} / \mathrm{kg} / \mathrm{day}$, radiation only, radiation plus MEVA at 250, and $500 \mathrm{mg} / \mathrm{kg} / \mathrm{day}$, and alpha-tocopherol (TOCO). Rats were treated for 14 days, irradiated on the $15^{\text {th }}$ day, and euthanized on the $16^{\text {th }}$ day. Bioassays of malondialdehyde for lipid peroxidation (LPO), reduced glutathione (GSH), catalase (CAT), and superoxide dismutase (SOD) were carried out using standard techniques. Some of the brains were processed for paraffin wax embedment and stained with haematoxylin and eosin. Data were analyzed using ANOVA. Radiation caused a significant $(\mathrm{p}<0.01)$ elevation in LPO by about $142 \%$. Pretreatment with $250 \mathrm{mg}$ MEVA, $500 \mathrm{mg}$ MEVA and TOCO reduced LPO significantly $(\mathrm{p}<0.01)$ by $56 \%, 65 \%$, and $80 \%$ respectively, when compared with rats that received gamma radiation only. There was improvement in the histological alterations in the cerebellar layers and the Purkinje cell parameters of the pretreated groups when compared with the gamma-irradiated (R) group. MEVA demonstrated antioxidant and radioprotective effects in rats' brain.

(C) 2010 International Formulae Group. All rights reserved.
\end{abstract}

Keywords: Radiotherapy, cancer, cerebellum, Vernonia amygdalina, alpha-tocopherol, free radicals.

\section{INTRODUCTION}

Both chemotherapy and radiation have played useful roles in cancer management, but they have been associated with side effects, which is due to their inability to distinguish between cancerous and normal cells. Radiation treatment, though a chief modality in the management of malignancies, faces some drawbacks due to the side effects generated as a result of tissue damage, despite adequate precautions by radiation oncologists (Sert et al., 2000). Radiation side effects include hair loss, tiredness, worsening of tumour symptoms and other pathological conditions like radiation encephalopathy, radiation myelopathy and vascular anomalies 
like vessel wall thickening, thrombosis, luminal occlusion, telangiectases (O'Connor and Mayber, 2000), and radiation myelopathy (Malomo et al., 2005).

It has been established that radiation pathology is mediated by free radical reactions leading to oxidative damage (Lee et al., 2006). The membrane of all aerobic organisms are susceptible to damage by reactive oxygen species (ROS) which consists of free radicals (FRs) like peroxyl radical $\left(\mathrm{RO}_{2}{ }^{\circ}\right)$, superoxide radical $\left(\mathrm{O}_{2}{ }^{\circ}\right)$, hydroxylradical $\left(\mathrm{OH}^{\circ}\right)$, and nitric oxide $(\mathrm{NO})$; as well as non-radicals exemplified by hydrogen peroxide $\left(\mathrm{H}_{2} \mathrm{O}_{2}\right)$, singlet oxygen $\left({ }^{1} \mathrm{O}_{2}\right)$, peroxynitrite $\left(\mathrm{ONOO}^{-}\right)$, ozone $\left(\mathrm{O}_{3}\right)$, and hypochlorous acid (HOCl) (Aruoma, 1998). Because of their reactivity, ROS have been implicated in pathologic processes such as carcinogenesis, inflammation, aging, and radiation damage among others (Liu et al., 2007).

An overabundance of FRs in the cells may lead to uncontrolled chain reactions with polyunsaturated fatty acids in cell membranes which ultimately lead to lipid peroxidation (LPO). Antioxidants (AO) are agents that neutralize ROS and reduce the molecular destruction that ROS mediate (Reiter et al., 2001; Farombi et al., 2008). AO do these by their ability to prevent or significantly delay the oxidation of the substrate when it is present at a low concentration compared to that of the oxidizable substrate (Halliwell, 1996). Plant derived AO are currently receiving much attention for their bioactivity, because of the remedial measures against various human and animal ailments (Visavadiya and Narasimhacharya, 2007). Alpha-tocopherol (vitamin E), a fat-soluble vitamin is a potent antioxidant and radical scavenger in chemical and biological systems, and functions mainly in maintenance of membrane integrity, thereby protecting the membrane from injury through its ability to prevent oxidation of unsaturated fatty acid (Cerecetto and Lopez, 2007).

The leaves of Vernonia amygdalina (bitter leaf) is readily available in Africa and is used as a vegetable spice and a medication for various ailments. The leaf extract contains flavonoids with antioxidant property which have been reported to inhibit lipid peroxidation as already demonstrated in hepatic tissue of rodents (Igile et al., 1994; Adaramoye et al., 2008). However, there is still an unanswered question concerning the antioxidant activity of this plant, because its effect on central nervous system (CNS) has not been reported. For instance, "Can Vernonia amygdalina leaf extract mitigate the gamma-radiation induced oxidative damage in rats' brain?" To answer this question, this study was designed to evaluate the antioxidant capacity of the leaf extract of Vernonia amygdalina to mitigate the effects of radiation injury in the brain of rats, using alpha tocopherol as a reference compound.

\section{MATERIALS AND METHODS \\ Chemicals}

Methanol $(\mathrm{MeOH})$, hydrogen peroxide $\left(\mathrm{H}_{2} \mathrm{O}_{2}\right)$, trichloroacetic acid (TCA), 2thiobarbituric acid (TBA), $5^{1}-5^{1}$ - dithiobis (2nitrobenzoic acid, DTNB), epinephrine, GSH, and other reagents were purchased from Sigma Chemical Co. USA. Alpha-tocopherol was purchased from Danax Pharmaceutical Store, Ibadan, Nigeria. All other reagents were from local firms and were of the highest analytical grade.

\section{Experimental animals}

Seventy male Wistar rats (Rattus novegicus), aged 10-14 weeks with initial body weight ranging between 130-160 g used for this study, were purchased from the Central Animal House of the College of Medicine, University of Ibadan, Ibadan and fed with commercial pelleted feed (Ladokun Feeds Nig. Ltd, Mokola, Ibadan), and water 
ad libitum. They were housed in transparent plastic cages with wood shavings at a fly proof, freely ventilated and naturally illuminated animal room. The University of Ibadan Ethical Committee approval was obtained and all procedures on animal handling conformed to the acceptable guidelines on the ethical use of animals in research (Clarke et al., 1996).

\section{Experimental design}

The rats were randomized into seven treatment groups of 10 animals per group and then allowed 5 days to acclimatize to animal room conditions before treatment. Group I was the control rats given $1 \mathrm{ml}$ distilled water (d.w)/rat daily x 14 days. Group II animals received $250 \mathrm{mg} / \mathrm{kg} /$ day of methanolic extract of $V$. amygdalina (MEVA) in $1 \mathrm{ml} \mathrm{d.w} \mathrm{daily}$ for 14 days. Group III animals received 500 $\mathrm{mg} / \mathrm{kg} /$ day of MEVA in d.w daily for 14 days, while Group IV animals received $1 \mathrm{ml} \mathrm{d.w}$ daily for 14 days +2.0 Gy gamma radiation treatment as a single dose on day 15 of the experiment. Group V rats received 250 $\mathrm{mg} / \mathrm{kg} /$ day of MEVA in d.w daily for 14 days +2.0 Gy gamma-radiation treatment as a single dose on day 15 of the experiments, while Group VI animals received 500 $\mathrm{mg} / \mathrm{kg} /$ day of MEVA in d.w daily for 14 days +2.0 Gy gamma-radiation treatment as a single dose on day 15 of the experiments. Group VII animals received $500 \mathrm{mg} / \mathrm{kg} /$ day of alpha-tocopherol (TOCO) for 14 days $+1 \mathrm{ml}$ d.w daily x 14 days +2.0 Gy gamma-radiation treatment as a single dose on day 15 of the experiments. All the treatments were given orally with a gavage. On the last day of the experiments, half of the rats were used for the antioxidant studies, while the other half was utilized for anatomical studies.

\section{Plant preparation and extraction procedures}

The leaves of Vernonia amygdalina Del ('bitter leaf') were harvested at a farm in
Ibadan, South-West Nigeria, in May, 2006. Botanical identification and authentication was done at the Forest Research Institute of Nigeria, Ibadan, Nigeria, where the voucher sample number FHI 107408, was deposited for reference. The leaves were rendered pestfree, and $4.55 \mathrm{~kg}$ of it extracted with pure $\mathrm{MeOH}(3 \times 17 \mathrm{~L})$ at room temperature with weekly changes of solvent, over a period of three weeks and solvent evaporated with a rotary vacuum evaporator (Eyela N.21, Tokyo) to afford a methanolic extract of $V$. amygdalina (MEVA) weighing $700 \mathrm{~g}$, a yield of $15.4 \%$.

\section{Preparation and administration of MEVA}

From MEVA, a stock solution of two different concentrations was prepared for this experiment, namely the $250 \mathrm{mg} / \mathrm{kg}$ and 500 $\mathrm{mg} / \mathrm{kg}$ concentrations, based on Abosi and Raseroka (2003).

$1 \mathrm{ml}$ of the prepared stock solution containing $250 \mathrm{mg} / \mathrm{kg} /$ day or $500 \mathrm{mg} / \mathrm{kg} /$ day was administered by gavage orally.

\section{Preparation and Administration of alpha- tocopherol (Vitamin E)}

Each capsule of $100 \mathrm{mg}$ vitamin $\mathrm{E}$ acetate (G. A. Pharmaceuticals, Athens, Greece) was aspirated with a size $21 \mathrm{G}$ needle, attached to an oral gavage, and administered orally at a dose of $500 \mathrm{mg} / \mathrm{kg} /$ orally daily for 14 days (Viana et al., 2003).

\section{Irradiation procedures}

Each experimental rat was anaesthetized with Ketamine hydrochloride injection (Rotex medica, Trittau, Germany, batch 40092) at $10 \mathrm{mg} / \mathrm{kg}$ body weight and Diazepam injection (Roche, Switzerland) at 3 $\mathrm{mg} / \mathrm{kg}$ body weight for muscle relaxation. Each rat was strapped down in a prone position in the specially designed cardboard box using cotton strapping. Each animal received irradiation as a single fraction of 2.0 Gy of gamma-rays at a dose rate of 106.965 
cGy/min, for $2.19 \mathrm{~min}$, obtained from a Cobalt-60 source. The radiation was delivered by an AECL Theratron 780C Teletherapy machine with energy of $1.25 \mathrm{MeV}$, at source to surface distance of $72 \mathrm{~cm}$, at a depth of 4 $\mathrm{cm}$, and a field size of $18 \mathrm{~cm}$ by $18 \mathrm{~cm}$, with an equivalent square area of $18 \mathrm{~cm}^{2}$; the percentage depth dose was $85.32 \%$. There was no shielding of any part of the rat's body. Rats were placed warm in cages and transferred to the animal room for recovery from anaesthesia.

\section{Euthanasia}

Rats in all groups were sacrificed on the $16^{\text {th }}$ day of the experiments.

\section{Sample collection}

The weight of each rat was obtained using a Swiss Microwa balance type 7720 on the $16^{\text {th }}$ day of the experiments, after which it was anaesthetized with Ketamine $10 \mathrm{mg} / \mathrm{kg}$ by the peritoneal route. A midline sagittal incision was made on the head and the brain of each rat dissected out, severed at the level of the cervico-medullary junction for uniformity, rinsed in ice-cold phosphate buffer, mopped with a Whatman filter paper, and then weighed with an Ohaus analytic balance (Switzerland). Thereafter each brain was immersed in 4 volumes of its weight in ice-cold phosphate buffer, $\mathrm{pH} 7.4$ and kept in the freezer. Brain samples were homogenized in a Potter-Elvehjem homogenizer. The homogenates was cold centrifuged (MSE cold centrifuge), at $12,500 \mathrm{~g}$ for 15 minutes at $4{ }^{\circ} \mathrm{C}$ to obtain the post mitochondrial supernatant fraction (PMF), which was aliquoted and used for the assay of antioxidant profile of the animals.

\section{Biochemical estimations: Determination of lipid peroxidation}

Lipid peroxidation was quantified as malondialdehyde (MDA) according to the method described by Farombi (1995) and
Farombi et al. (2000), and expressed as units/mg protein.

\section{As assay of Gluta (GSH)}

Reduced GSH was determined at 412 $\mathrm{nm}$ using the method described by Jollow et al. (1974).

\section{Enzyme assay}

Superoxide dismutase (SOD) activity in the homogenates of whole brain of rats was determined by measuring the inhibition of auto-oxidation of epinephrine at $\mathrm{pH} 10.2$ at $30{ }^{\circ} \mathrm{C}$ according to Misra (1972). Catalase (CAT) activity was estimated using hydrogen peroxide as substrate according to the method of Sinha (1972).

\section{Protein determination}

Protein concentration of brain homogenate was determined by means of the Biuret reaction as described by Gornall et al. (1949) with some slight modifications.

\section{Histopathological preparations}

Cerebellar tissue obtained from the animals allocated for histological studies in each group was fixed with $10 \%$ formol saline and processed by the routine method for paraffin wax embedment sections. 5-6 $\mu \mathrm{m}$ thick transverse sections of the cerebellum were obtained by microtomy, and the slides stained with Haematoxylin and Eosin. They were examined and then evaluated under the light microscope (Olympus CH Japan).

\section{Histomorphometry}

The dimensions of the molecular layer, Purkinje layer, granular layer, maximum width of Purkinje cells, and the density of the Purkinje cells were obtained by the use of a microscope with a graticule (Leitz Wetzlar, Germany), at different magnifications. The calibration of the graticule was done such that: 1 interval was equivalent to 30,13 and 3 micrometers at magnification of 40, 100 and 400 respectively.

The density of Purkinje cells was measured by counting the number of Purkinje cells that have nuclei observed within a given 
square area of the circular view in a section (Sugihara et al., 2000), utilizing the eyepiece of an Olympus $\mathrm{CH}$ (Japan) binocular microscope at $\mathrm{x} 40$ magnification. With the radius of the eye piece calibrated with the graticule to be $0.19 \mathrm{~mm}$, the area of the view was thus estimated as $0.11 \mathrm{~mm}^{2}$ as described by Osuagwu et al. (2007). Three separate measurements were made on each section from all the experimental and control groups, and the mean of the sum of each of the dimensions obtained was then calculated.

\section{Statistical analysis}

Results are expressed as mean \pm S.D. Data were analysed with one-way ANOVA, and Tukey post-test performed for multiple comparisons using GraphPad Prism version 4.0 (2003) for Windows GraphPad Software, SanDiego, California, USA, (www.graphpad.com). Statistical significance was set at $\mathrm{p}<0.05$, for the null hypothesis being true by chance.

\section{RESULTS}

\section{General}

The animals tolerated the treatments and did not suffer post-irradiation diarrhoea or lethargy, and were fully awake and active 2-3 hours after anaesthesia and irradiation.

\section{Effect of treatments on lipid peroxidation (LPO)}

Table 1 shows that gamma radiation (R) caused $142 \%$ increase in lipid peroxidation when compared with the control group which was statistically significantly ( $\mathrm{p}<0.01) . \mathrm{R}+\mathrm{M} 250, \mathrm{R}+\mathrm{M} 500$, and $\mathrm{R}+\mathrm{TOCO}$ treatments when compared with $\mathrm{R}$ shows statistically significant lower values $(\mathrm{p}<0.01)$.

\section{Effect of treatments on Glutathione (GSH)}

Treatment with $\mathrm{R}$ elicited a nonsignificant increase of GSH as compared with the control (Table 1). Similarly, treatments with M250, M500, R+M250, R+M500, and
$\mathrm{R}+\mathrm{TOCO}$, elicited increases in the means of GSH, which were not significant $(p>0.05)$, when compared with the $\mathrm{R}$ treatment as shown in the same table.

\section{Effect of treatments on superoxide dismutase (SOD)}

Treatment with $\mathrm{R}$ caused an increase in the values of SOD when compared with the control in a non-significant manner as presented in Table 2. Similarly, the effects of treatments with M250, M500, R+M250, $\mathrm{R}+\mathrm{M} 500$, and $\mathrm{R}+\mathrm{TOCO}$ on SOD were not statistically different from the control or the $\mathrm{R}$ group ( $p>0.05$ ).

\section{Effect of treatments on catalase (CAT)}

Table 2 shows that $\mathrm{R}$ increased the values of CAT in a non-significant manner when compared with the control. Similarly, treatments with M250, M500, R+M250 and $\mathrm{R}+\mathrm{TOCO}$ were not statistically different from $\mathrm{R}$ ( $\mathrm{p}>0.0 .5$ ), whereas $\mathrm{R}+\mathrm{M} 500$ caused a significant $(p<0.05)$ increase in the mean of CAT when compared with the $\mathrm{R}$ treatment.

\section{Effect of treatments on brain protein}

$R$ caused a non-significant decrease in brain protein. $\mathrm{R}+\mathrm{M} 500$ elevated the brain protein levels, significantly $(\mathrm{p}<0.05)$, while it was non-significantly elevated in the $\mathrm{R}+\mathrm{M} 250$ and $\mathrm{R}+\mathrm{TOCO}$ groups. These results are shown in Table 2.

\section{Effects of treatment on histology}

Figures 1A-1E show the photomicrographs of the representative cerebellum of the rats in this study. In addition to the paucity, the Purkinje cells in the $\mathrm{R}$ group were observed to be irregularly separated, with a diminution in the size of the bodies when compared with the control, while the histological features show much improved features in the pretreated groups ( $\mathrm{R}+\mathrm{M} 250$, $\mathrm{R}+\mathrm{M} 500$, and R+TOCO groups), when compared with the $\mathrm{R}$ group. 

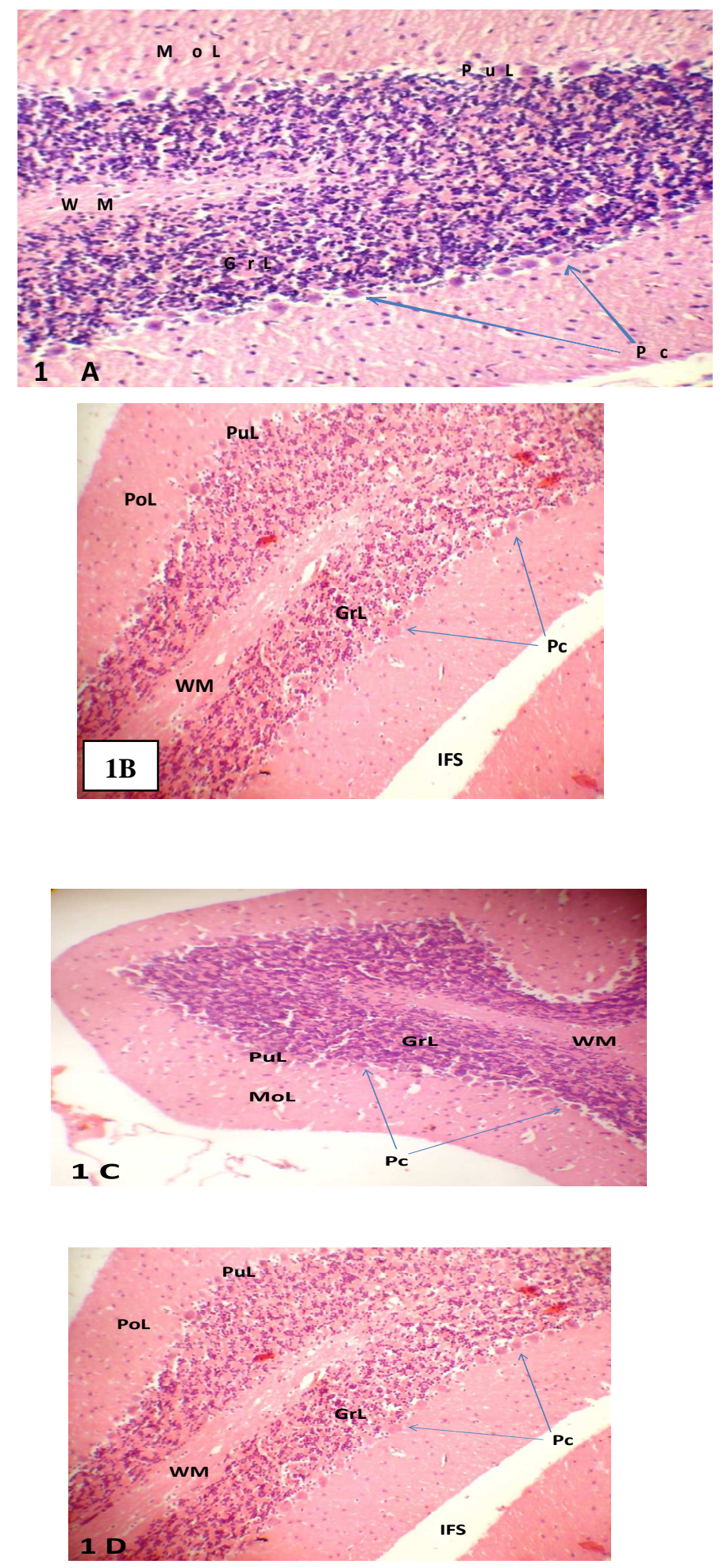


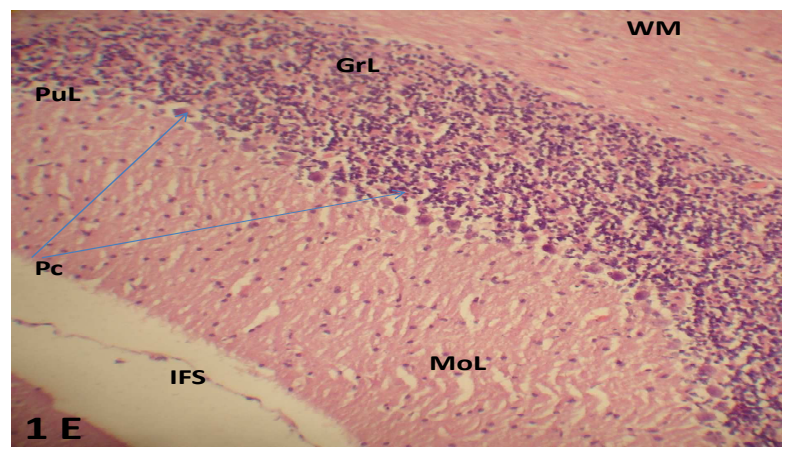

Figure 1: Histological changes in the cortex of the cerebellum following administration of $\mathrm{R}+\mathrm{M} 250, \mathrm{R}+\mathrm{M} 500, \mathrm{TOCO}$ and R. Representative photomicrographs of rat cerebellum from control (1 A), R (1 B), $\mathrm{R}+\mathrm{M} 250(1 \mathrm{C}), \mathrm{R}+\mathrm{M} 500(1 \mathrm{D})$ and R+TOCO (1 E) are shown. The alteration of the Purkinje cell by R treatment is noted in Figure $1 \mathrm{~B}$. The amelioration of this effect can be observed in Figures $1 \mathrm{C}-1 \mathrm{E}$. (H \& E staining, original magnification $\mathrm{x}$ 160). $\mathrm{MoL}=$ molecular layer; $\mathrm{PuL}=$ Purkinje layer; $\mathrm{GrL}=$ granular layer; $\mathrm{IFS}=$ interfolial space; $\mathrm{Pc}=$ Purkinje cell; $\mathrm{WM}=$ white matter.

Table 1: Effect of MEVA, $\alpha$-tocopherol and $\gamma$-radiation on reduced glutathione (GSH) and lipid peroxidation (LPO).

\begin{tabular}{lccc}
\hline Group & Treatment & $\begin{array}{c}\text { LPO (units/mg } \\
\text { protein) }\end{array}$ & GSH $(\boldsymbol{\mu g} / \mathbf{g}$ tissue) \\
\hline I & Control & $0.722 \pm 0.52$ & $7.394 \pm 0.65$ \\
II & M250 & $0.685 \pm 0.31$ & $10.251 \pm 1.17$ \\
III & M500 & $0.64 \pm 0.15$ & $8.947 \pm 0.70$ \\
IV & R & $1.749 \pm 0.21^{\mathrm{a} * *}$ & $8.694 \pm 0.94$ \\
V & R + M250 & $0.767 \pm 0.42^{b_{* *}}$ & $10.350 \pm 0.88$ \\
VI & R + M500 & $0.511 \pm 0.18^{b_{* *}}$ & $9.544 \pm 1.28$ \\
VII & R + TOCO & $0.386 \pm 0.08^{b_{* *}}$ & $7.544 \pm 0.57$ \\
\hline
\end{tabular}

Values are given as means \pm S.D., $(\mathrm{n}=5)$. MEVA - methanolic extract of Vernonia amygdalina; $\mathrm{R}-$ radiation; $\mathrm{M}$ 250 - MEVA at $250 \mathrm{mg} / \mathrm{kg}$; M 500 - MEVA at $500 \mathrm{mg} / \mathrm{kg}$; TOCO $-\alpha$-Tocopherol; ${ }^{a} * *$ p $<0.01$ versus control; ${ }^{b * *}$ p $<$ 0.01 versus $R$.

Table 2: Effect of MEVA, $\alpha$-tocopherol and $\gamma$-radiation on catalase, superoxide dismutase (SOD), and brain protein.

\begin{tabular}{l|l|c|c|c}
\hline Group & Treatment & $\begin{array}{c}\text { Brain protein }(\mathbf{m g} / \mathbf{g} \\
\text { tissue) }\end{array}$ & $\begin{array}{c}\text { Catalase (/g } \\
\text { tissue }\end{array}$ & SOD (units/g) \\
\hline I & Control & $2.450 \pm 1.16$ & $0.104 \pm 0.03$ & $2.457 \pm 0.42$ \\
II & M250 & $2.80 \pm 1.18$ & $0.091 \pm 0.00$ & $2.283 \pm 0.83$ \\
III & M500 & $2.522 \pm 1.38$ & $0.140 \pm 0.02$ & $3.480 \pm 0.39$ \\
IV & R & $1.991 \pm 1.13$ & $0.147 \pm 0.03$ & $4.248 \pm 1.79$ \\
V & R + M250 & $2.932 \pm 0.88$ & $0.130 \pm 0.04$ & $4.010 \pm 1.65$ \\
VI & R + M500 & $3.071 \pm 0.91 *$ & $0.210 \pm 0.03 *$ & $3.467 \pm 0.62$ \\
VII & R + TOCO & $0.118 \pm 0.03$ & $3.193 \pm 0.78$ \\
\hline \multicolumn{2}{l|}{ Values are given as mean \pm S.D., $(\mathrm{n}=5)$. MEVA - methanolic extract of Vernonia amygdalina; R - radiation; M 250- }
\end{tabular}

MEVA at $250 \mathrm{mg} / \mathrm{kg}$; M 500 - MEVA at $500 \mathrm{mg} / \mathrm{kg}$; TOCO - $\alpha$-Tocopherol; * p $<0.05$ versus R. 
Effects of treatment on histomorphometry

Table 3 shows that $R$ caused a statistically significant decrease in the molecular layer (MoL), Purkinje cell layer (PuL), and granular layer (GrL) of the cerebellum by $32.2 \%$ ( $\mathrm{p}<0.001), 10.2 \%$ ( $\mathrm{p}<$ $0.05)$ and $29.6 \%(\mathrm{p}<0.001)$ respectively as compared with the control. However, pretreatment elicited increases in the dimensions of the MoL, PuL, GrL by $6.8 \%$, $3.8 \%$, and $10.6 \%$ respectively in the $\mathrm{R}+\mathrm{M}$ 500 group when compared with the $\mathrm{R}$ group. Similarly, the $\mathrm{R}+\mathrm{TOCO}$ group recorded increases in the dimensions of MoL, PuL, GrL by $14.2 \%, 13.2 \%$, and $38.8 \%$ respectively when compared with the $\mathrm{R}$ group.
The effects of treatments on the density of Purkinje cells are presented in Table 4 which shows the significant reduction of the density by $\mathrm{R}$ by about $32.7 \%$ when compared with the control. This was significantly improved by pretreatment, which shows increased diameter by $49.3 \%$ (R+M250), $52.5 \%$ (R+M500), 59.1\% (R+TOCO), when compared with the R group. Similarly, Table 4 shows the significant reduction of the maximal diameter of Purkinje cells by $\mathrm{R}$ by about $34 \%$ when compared with the control. This was significantly elevated by pretreatment, which shows increase of the diameter by $28.4 \% \quad(\mathrm{R}+\mathrm{M} 250), \quad 25.9 \%$ (R+M500), 52.4\% (R+TOCO) ( $<<0.001)$, when compared with the $\mathrm{R}$ group.

Table 3: Effect of MEVA, $\alpha$-tocopherol and $\gamma$-irradiation on the molecular layer (MoL), Purkinje layer $(\mathrm{PuL})$, and granular layer $(\mathrm{GrL})$, of the cerebellum of Wistar rat.

\begin{tabular}{lccccccc}
\hline Group & Control & M250 & M500 & R & $\begin{array}{c}\text { R }+ \\
\text { M250 }\end{array}$ & $\begin{array}{c}\text { R + } \\
\text { M500 }\end{array}$ & R + TOCO \\
\hline MoL & $182.4 \pm$ & $180.8 \pm$ & $181.2 \pm$ & $123.6 \pm$ & $134.4 \pm$ & $132.0 \pm$ & $132.0 \pm$ \\
$(\mu \mathrm{m})$ & 5.0 & 5.91 & 5.78 & $7.81^{\mathrm{a} * * *}$ & $4.08^{\mathrm{b} *}$ & $4.19^{\mathrm{b} *}$ & $5.64^{\mathrm{c} * *}$ \\
\hline $\mathrm{PuL}$ & $23.6 \pm$ & $22.8 \pm$ & $23.2 \pm$ & $21.2 \pm$ & $21.6 \pm$ & $22.0 \pm$ & $24.0 \pm$ \\
$(\mu \mathrm{m})$ & 1.5 & 0.98 & 0.98 & $0.98^{\mathrm{a} *}$ & 0.8 & 1.26 & $2.01^{\mathrm{b} *}$ \\
\hline $\mathrm{GrL}$ & $136.4 \pm$ & $135.0 \pm$ & $135.6 \pm$ & $96.0 \pm$ & $104.6 \pm$ & $106.2 \pm$ & $133.4 \pm$ \\
$(\mu \mathrm{m})$ & 1.50 & 0.63 & 3.87 & $0.62^{\mathrm{a}}{ }^{* * *}$ & $1.36^{\mathrm{b} * * *}$ & $1.93^{\mathrm{b} * * *}$ & $0.54^{\mathrm{b}_{* * *} *}$ \\
\hline
\end{tabular}

Values are given as means \pm S.D., $(\mathrm{n}=5)$. MEVA - methanolic extract of Vernonia amygdalina; $\mathrm{R}-$ radiation; M250 MEVA at $250 \mathrm{mg} / \mathrm{kg}$; M500 - MEVA at $500 \mathrm{mg} / \mathrm{kg}$; TOCO - $\alpha$-Tocopherol; ${ }^{\mathrm{a} *} \mathrm{p}<0.05$, ${ }^{\mathrm{a} * * *} \mathrm{p}<0.001$ versus control; ${ }^{\mathrm{b} *}$ $\mathrm{p}<0.05$ versus $\mathrm{R} ;{ }^{\mathrm{b} * * *} \mathrm{p}<0.001$ versus $\mathrm{R} ;{ }^{{ }^{*} * *} \mathrm{p}<0.01$ versus $\mathrm{R}$.

Table 4: Effect of MEVA, $\alpha$-tocopherol and $\gamma$-irradiation on the density of Purkinje cells (DPc) and the maximal diameter of Purkinje cells (MDPc) of the cerebellum of rats.

\begin{tabular}{llllllll}
\hline Group & Control & M250 & M500 & R & R + M250 & R + M500 & $\begin{array}{l}\text { R + } \\
\text { TOCO }\end{array}$ \\
\hline DPc & $8.2 \pm$ & $8.14 \pm$ & $8.26 \pm$ & $5.52 \pm$ & $8.24 \pm$ & $8.42 \pm$ & $8.78 \pm$ \\
$\left(\mathrm{no} / 0.11 \mathrm{~mm}^{2}\right)$ & 0.16 & 0.12 & 0.17 & $0.24^{\mathrm{a} * * *}$ & $0.21^{\mathrm{b}_{* * *}}$ & $0.07^{\mathrm{b}_{* * *}}$ & $0.57^{\mathrm{b}_{* * *}}$ \\
$\mathrm{MDPc}$ & $12.28 \pm$ & $12.3 \pm$ & $12.30 \pm$ & $8.1 \pm$ & $10.4 \pm$ & $10.2 \pm$ & $12.34 \pm$ \\
$(\mu \mathrm{m})$ & 0.12 & 0.12 & 0.17 & $0.11^{\mathrm{a} * * *}$ & $0.36^{\mathrm{b}_{* * *}}$ & $0.17^{\mathrm{b}_{* * *}}$ & $0.24^{\mathrm{b}_{* * *}}$ \\
\hline
\end{tabular}

Values are given as means \pm S.D., $(\mathrm{n}=5)$. MEVA - methanolic extract of Vernonia amygdalina; $\mathrm{R}-\mathrm{radiation} ; \mathrm{M} 250$ MEVA at $250 \mathrm{mg} / \mathrm{kg} ; \mathrm{M} 500$ - MEVA at $500 \mathrm{mg} / \mathrm{kg}$; TOCO $-\alpha-$ Tocopherol; ${ }^{\mathrm{a} * * *} \mathrm{p}<0.001$ versus control; ${ }^{\mathrm{b} * * *} \mathrm{p}<0.001$ versus R. 


\section{DISCUSSION}

In this work, we addressed the question: "Can Vernonia amygdalina leaf extract mitigate the gamma-radiation induced oxidative damage in rats' brain?" The present study demonstrated that gamma radiation caused a significant elevation of lipid peroxidation as monitored by the levels of malondialdehyde in the brain homogenates. It also showed that pretreatment with both MEVA and TOCO for fourteen days before irradiation significantly reduced the effects of irradiation by the lower levels of lipid peroxidation in the pretreated groups as compared with the irradiation rats only. Similarly, the histological alterations caused by the irradiation in cerebellar tissue were improved by pretreatment with MEVA and TOCO.

Only radiation treatment resulted in significant elevation of lipid peroxidation which was in consonance with previous reports of toxicity studies that showed the liability of a highly lipid membranous tissue like the brain to lipid peroxidation (Reiter et al., 2001). Oxidative damage by toxicants on lipid membranes of cells might also be due to radiolysis of intracellular water which then releases free radicals that further generate more free radicals in the system. The presence in abundance of poly unsaturated fatty acids (PUFA) in the myelin components of axons of the millions of neurons in the brain provide a ready source of target for the gamma radiation bombarding the brain to release free radicals that will cause lipid peroxidation of these membranes (Demopoulus, 1975; Cook and Samman, 1996; Aruoma, 1998).

The significant reduction of lipid peroxidation in the brains of the $\mathrm{R}+\mathrm{M} 250$ and $\mathrm{R}+$ M500 groups as compared with the $\mathrm{R}$ group might be due to the antioxidant property exhibited by MEVA. This in vivo observation was in consonance with the in vitro study findings of Igile et al. (1994), who reported the antioxidant activity and presence of flavonoids such as luteolin, luteolin 7-0, $\beta$ glucuronide and $\beta$-glucoside in the methanolic extract of the leaves of Vernonia amygdalina. Flavonoids are established antioxidants (Cook and Samman, 1996; Markham and Bloor, 1998). Furthermore, this observation in addition with the fact that a lower value of lipid peroxidation in the $\mathrm{R}+500$ group when compared with the $\mathrm{R}+250$, suggests a dose dependent activity in the antioxidant property. All these are in agreement with the report of Adaramoye et al. (2008) who also noted this same trend in their study of antioxidant activity using serum and liver homogenates.

The significant reduction in the level of lipid peroxidation in the animals of $\mathrm{R}+$ TOCO group when compared with rats of the $\mathrm{R}$ group suggests a potent antioxidant activity by the alpha-tocopherol, which is a standard antioxidant compound. This is in agreement with earlier reports of the ability of alphatocopherol (Vitamin E), to reduce lipid peroxidation especially in fatty tissue, abundance of which is to be found in the brain (Cerecetto and Lopez, 2007). Alphatocopherol is the most active of the tocopherols against peroxyl radicals. The antioxidant activity of Vitamin $\mathrm{E}$ is based on the ease with which the hydrogen on the hydroxyl group of the chroman ring can be donated to neutralize a free radical and thereby create a more stable tocopheroxyl radical (Pauling, 2008).

The elevation of the levels of superoxide dismutase (SOD) and catalase (CAT), and reduced glutathione (GSH), in animals of the $\mathrm{R}$ group when compared with the control suggests that these enzymes were up regulated to respond to the toxicity induced by the radiation. This observation may be due in part to the effects of acid and basic fibroblast growth factor (aFGF and bFGF), 
both of which play a variety of roles in the response to acute neural injury. Brain insult induces marked increases of gene expression for FGFs in cortical and hippocampal neurons which are followed by increased FGFs protein levels (Cuevas and Gimenez-Gallego, 1997). It has been reported that following CNS insult, the early primary cellular protective response which occurs in the first few hours (also termed "protective process") include increases of FGF gene transcription and translation leading to (a) overproduction of FGF, (b) increased activity of $\mathrm{Ca}^{++}$binding neurons, (c) decreased NMDA receptor expression, and (d) increased synthesis of antioxidant enzymes. While (b) and (c) normalize $\mathrm{Ca}^{++}$homeoastasis, (d) protects against free radical damage, the overall result being cell survival (Cueva and GimenezGallego, 1997; Juurlink and Paterson, 1998). This may then be followed by the secondary reparative response referred to as "late events" or "reparative process" which comes on days after. This is associated with processes like angiogenesis, astrogliosis, reactive oligodendroglia and microglia. The animals involved in this study were euthanized between sixteen to twenty four hours after receiving radiation treatment. This timing of antioxidant analysis i.e. sacrifice of the animals within twenty four hours postirradiation, might therefore explain the rise in the levels of these antioxidants in the present study, as it as has been established that free radical generation following brain insults peak at about 6 hours of onset and thereafter begins to slow down (Olive et al., 1995; Tyurin et al., 2000; Reiter et al., 2001).

The relatively lower values of SOD recorded in the $\mathrm{R}+\mathrm{TOCO}$ group of rats as compared with those that of $\mathrm{R}$ group confirmed that TOCO a standard antioxidant, might have augmented the body's reserve of antioxidants in mopping up the ROS produced by the radiation toxicity.

In the $\mathrm{R}+\mathrm{TOCO}$ group of rats, the decrease of CAT might be due to the possibility of its being used up in the augmentation of the antioxidant store of the body. This is in agreement with reports from earlier workers in toxicology studies who observed the effect on vitamin E pretreated animals (Pauling, 2008).

The anatomical alterations observed namely, reduction in size of the layers of the cerebellum and Purkinje cell density, as well as the Purkinje cell diameter by gamma radiation might be due to the CNS toxicity which is well reported in literature (Belka et al., 2001; Malomo et al., 2005). Raza (2006) reported that reducing the distance from the radiation beam increases the risk of exposure and that shielding will significantly reduce the risk of exposure. In this experiment, the source to surface distance was only $72 \mathrm{~cm}$ and there was no shielding. This may suggest that since the radiation dose ( 2 Gy) exceeded the acute radiation dose, about 10 rads $(0.1 \mathrm{~Gy})$, immediate cellular or organ damage could have occurred (Ehow how. com., 2010). Ionizing radiation has been reported to induce cell death and reduce the size of the brain if given in excess of acute radiation dose, which was the setting in this experiment (Ferrer, 1996). The changes observed might therefore, be a cumulative effect of these cell deaths.

The radiation injuries observed in the cerebellar tissues in this study could affect the dentatorubral fibres, the main efferent nervous outflow from the cerebellum, thus affecting the functional integrity of the cerebellum. This might theoretically lead to abnormalities like loss of muscular coordination, cerebellar ataxia, asthenia, hypotonia, dysmetria, intention tremors, nystagmus and decomposition of movements, amongst others. The possible effects of cerebellar injury as a 
consequence of radiotherapy justifies the need for pursuing active preventive measures, hence the significance of the results that pretreatment with MEVA and TOCO alleviated these histological effects.

\section{Conclusion}

This study has demonstrated that the administration of the methanolic extract of the leaves of Vernonia amygdalina and alphatocopherol as pretreatment before irradiation mitigated the lipid peroxidative response of the brain tissue to radiotherapy. This appears to be the first report of the neuroprotective effect of MEVA on biochemical and histological changes induced by gamma radiation in the brain of rats.

\section{ACKNOWLEDGEMENTS}

We thank Dr Absa Ndiaye and Pr Abdoulaye Samb for their very helpful review and criticism of the manuscript. We also thank CTA/CRAT for his training on scientific writing. This study is partially financed by FNRAA. Facilities were provided by Institut Sénégalais de Recherches Agricoles (ISRA) and Institut de Recherche pour le Développement (IRD).

\section{REFERENCES}

Adaramoye O, Ogungbenro B, Anyaegbu O, Fafunso M. 2008. Protective effects of extracts of Vernonia amygdalina, Hibiscus sabdariffa and vitamin $\mathrm{C}$ against radiation- induced liver damage in rats. $J$. Radiat Res., 49: 123-131.

Abosi AO, Raseroka BH. 2003. In vivo antimalarial activity of Vernonia amygdalina. Br. J. Biomed. Sci., 60(2): 89-91.

Aruoma O. 1998. Free radicals, oxidative stress, and antioxidants in human health and disease. JAOCS, 75(2): 199-208.
Belka C, Budach W, Kortmann RD, Bamberg M. 2001. Radiation induced CNS toxicity-molecular and cellular mechanisms. Br. J. Cancer, 85(9): 12331239.

Cerecetto H, Lopez GY. 2007. Antioxidants derived from Vitamin E: An Overview. Mini-Reviews in Medicinal Chemistry, 7: 315-338.

Clarke JD. 1996. The guide for the care and use of laboratory animals. National Academy of Science Revision Committee.

Cook NC, Samman S. 1996. Flavonoidschemistry, metabolism, cardioprotective effects and dietary sources. J. Nutr. Biochem., 7: 66-76.

Cuevas P, Gimenez-Gallego G. 1997. Role of fibrolast growth factors in neural trauma. Neurological Research, 19: 254-256.

Demopoulos, HB. 1975. The basis of free radical pathology. Free radical pathology, Federation Proceedings, 32(8): 1859-1861.

Ehow. Com. Retrieved on March 20, 2010 from http://www.ehow.com/howdoes_5498108_effects-acute-radiationdose.html

Farombi EO. 1995. Modulatory effect of browned yam flour diet on drug induced toxicity in rat. Ph.D thesis, University of Ibadan, Ibadan.

Farombi EO. 2000. Mechanisms for the hepatoprotective action of kolaviron: studies on hepatic enzymes, microsomal lipids and lipid peroxidation in carbon tetrachloride-treated rats. Pharmacol. Res., 42: 75-80.

Farombi EO, Ugwuezumba MC, Ezenwadu TT, Oyeyemi MO, Martins E. 2008. Tetracycline- induced reproductive toxicity in male rats: Effects of vitamin $\mathrm{C}$ and $\mathrm{N}$-acetylcysteine. Exp. \& Toxicol. Pathol, 60: 77-85. 
Ferrer I. 1996. Cell death in normal developing brain and following ionizing radiation, methyl-azoxymethanol acetate and hypoxia-ischemia in the rat. Neuropathol \& App. Neurobiol, 22(6): 489-494.

Gornall AG, Bardonill JC, David MM. 1949. Determination of serum protein by means of biuretic reaction. J. Biol. Chem., 177: 751-766.

Halliwell B. 1996. Antioxidants in human health and disease. Ann Rev Nutr 16: 3350.

Igile GO, Oleszek W, Jurzysta M, Burda S, Fafunso M, Fasanmade AA. 1994. Flavonoids from Vernonia amygdalina and their antioxidant activities. J. Agric. Food Chem., 42: 2445-2448.

Jollow DJ, Mitchell JR, Zampaglione N, Gillete JF. 1974. Bromobenzene-induced liver necrosis. Protective role of glutathione and evidence for 3, 4bromobenzene oxide as the hepatotoxic metabolite. Pharmacology, 11: 151-169.

Juurlink BHJ, Paterson PG. 1998. Review of oxidative stress in brain and spinal cord injury: Suggestions for pharmacological and nutritional management strategies. $J$. Spinal Cord Medicine, 21: 309-334.

Lee HJ, Kim SR, Kim JC, Kang CM, Lee YS, Jo SK, Kim TH, Jang JS, Nah SY, Kim SH. 2006. In vivo radioprotective effect of Panax ginseng C.A and identification of active Ginsenosides. Phytother. Res., 20: 392-395.

Liu Q, Xie F, Rolston R, Moreira PI, Nunomura A, Zhu X, Smith MA, Perry G. 2007. Prevention and treatment of Alzheimer disease and aging: antioxidants. Mini-Reviews in Medicinal Chemistry, 7: 171-180.

Malomo AO, Owoeye O, Elumelu TN, Akang EEU, Adenipekun A, Campbell OB, Shokunbi MT. 2005. The effect of dexamethasone, metronidazole and ascorbic acid on the morphological changes induced by gamma rays on the spinal cord of Wistar rats. Afr. J. Med. Med. Sci., 34: 161-165.

Markham KR, Bloor SJ. 1998. Analysis and identification of flavonoids in practice. In: Flavonoids in Health and Disease, Rice-Evans CA, Lester P (eds). Marcel Dekker Inc: New York; 1-32.

Misra HP, Fridovich L. 1972. The role of superoxide anion in the autooaxidation of epinephrine and a simple assay for superoxide dismutase. J. Biol. Chem., 217(10): 3170-3175.

O'Connor MM, Mayberg MR. 2000. Effects of radiation on cerebral vasculature: a review. Neurosurgery, 46(1): 138-49.

Olive M, Blanco R, Rivera R, Cinos C, Ferrer I. 1995. Cell death induced by gamma irradiation of developing skeletal muscle. J. Anat., 187: 127-132.

Osuagwu FC, Owoeye O, Avwioro GO, Oluwadara OO, Imosemi IO, Ajani RS, Ogunleye AA, Oladejo OW. 2007. Reduction of Hippocampal CA 1 neurons in Wistar rats following the administration of Phenytoin. Afr. J. of Med. and med. Sciences, 36: 103-108.

Pauling L. 2006. Vitamin E. Retrieved October 20, 2008 from http://lpi.oregonstate.edu/nifocenter/vitam ins/vitamin E/.Raza SMS. Radiation exposure in the cath lab - safety and precautions. Retrieved on October 26, 2010 from http://priory.com/med/radiation.htm

Reiter RJ, Acuna-Castroviejo D, Tan D-X, Burkhardt S. 2001. Free radical-mediated molecular damage. Mechanisms for the protective actions of melatonin in the central nervous system. Ann. N. Y. Acad. Sci., 939: 200-215. 
Sert C, Celik MS, Akdag Z, Ketani MA, Nergiz Y. 2000. The radioprotective effect of vitamins $\mathrm{C}, \mathrm{E}$ and vitamin $\mathrm{E}+$ Glutathione on the small intestine and the thyroid in rats irradiated with X-rays. Turk. J. Med. Sci., 30: 417-425.

Sinha KA. 1972. Colorimetric assay of catalase. Ann. Biochm., 47: 389-394.

Sugihara I, Bailly Y, Mariani J. 2000. Olivocerebellar climbing fibers in the granuloprival cerebellum: Morphological study of individual axonal projections in the X-irradiated Rat. J. Neurosci., 20(10): 3745-3760.

Tyurin VA, Tyurina YY, Borisenko GG, Sokolova TV, Ritov VB, Quinn PJ, Rose
M, Kochanek P, Graham SH, Kagan VE. 2000. Oxidative stress following traumatic brain injury in rats: quantification of biomarkers and detection of free radical intermediates. $J$. Neurochem., 75: 2178-89.

Viana M, Castro M, Barbas C, Herrera E, Bonet B. 2003. Effect of different doses of vitamin $\mathrm{E}$ on the incidence of malformations in pregnant diabetic rats. Ann Nutr Metab., 47(1): 6-10.

Visavadiya NP, Narasimhacharya AVRL. 2007. Hypocholesteremic and antioxidant effects of Withania somnifera (Dunal) in hypercholesteremic rats. Phytomedicine, 14: 136-142. 